\title{
Comparison of ISO and ASTM standards in determining the flexural strength of denture base resin
}

\section{Purpose}

The aim of this study was to compare the differences between the ASTM D790 and ISO 20795.1.2013 standards in evaluating the flexural strength of heat cure poly methyl methacrylate (PMMA) denture base resin.

\section{Materials and Methods}

30 heat cure denture base samples were fabricated in accordance to ISO 20795.1.2013 and ASTM D790 Standards. The specimens were finished and stored following the standardized protocol. The flexural strength was determined using universal testing machine at cross head speed of $1.50 \mathrm{~mm} / \mathrm{min}$ and a span length of $40.00 \mathrm{~mm}$. The mean flexural strength values were calculated in megapascals ( $\mathrm{MPa}$ ), and statistically analyzed.

\section{Results}

The mean flexural strength of heat cure PMMA found with ISO and ASTM ranged between $60.492 \mathrm{MPa}$ and $61.470 \mathrm{MPa}$. There was no significant difference between the two methods.

\section{Conclusion}

The quantitative differences existed in the flexural strength of denture base resin between ISO 20795.1.2013 and ASTM 790 protocols but those differences had no statistical and clinical significance.

Keywords: ISO; ASTM; denture base; poly methyl methacrylate; resin

\section{Introduction}

The flexural strength is the primary mode of evaluation for any additions, reinforcements, modifications and composition changes in denture base materials $(1,2)$. The assessment of acrylic denture bases by bend-testing was first done by National Bureau of Standards in the United States of America. The evolution in the standards and testing equipments has followed from 1930s (3). Sweeney et al. (4), Osborne (5), Souder and Paffenbarger (6) have made significant contributions to the evaluation criteria. The testing techniques such as water cycling machines, continuous loading, and evaluation in dry and moist conditions have evolved over the years (7). Currently, the literature accepts and supports the guidelines of ISO protocol for the evaluation and it is constantly been amended to the needs and requirements. The optimized methodology was adapted and followed by standard organization of all countries. The present guidelines are more structured towards denture base materials applications $(8,9)$.

Numerous studies in the literature evaluated the flexural strength of the various dentures base materials (10-12). However, considerable variations exist in the analysis procedures. Three point bending and four point

\author{
N.Gopi Chander ${ }^{1}$ (D), \\ Venkatraman Jayaraman² (1), \\ Venkat Sriram ${ }^{3}$ (D)
}

\footnotetext{
ORCID IDs of the authors: N.G.C. 0000-0002-2040-4550; V.J. 0000-0002-1627-7237; V.S. 0000-0002-6265-5550

${ }^{1}$ Research Scholar Department of Prosthodontics SRM Dental College, Ramapuram Chennai, India

${ }^{2}$ Department of Medicine SRM Dental College, Ramapuram, Chennai, India

${ }^{3}$ Department of Prosthodontics SRM Dental College, Ramapuram, Chennai, India

Corresponding Author: N.Gopi Chander E-mail:drgopichander@gmail.com

Received: 28 November 2018 Revised: 14 February 2019 Accepted: 21 March 2019 DOI: 10.26650/eor.20190072
} 
bending tests are commonly employed and few studies have used outdated guidelines (13). The distribution of stress varies between three and four point bending test. The four point bending causes stress distribution whereas three point leads to stress concentration. The difference in standards influence the sample size, shape, analysis procedure and the outcome $(2,13,14)$. Consensus is required in following the particular protocol for dental material analysis (3).

The objective of this study is to evaluate the quantitative differences in the flexural strength in three and four point bending test of heat cure acrylic denture base resin.

\section{Materials and Methods}

\section{Sample preparation}

The consent and approval for the study was obtained from Institutional review board and ethical committee. The master die for the test samples were prepared in accordance to ISO and ASTM regulation. The dimension of $65 \mathrm{~mm} \times 40 \mathrm{~mm}$ x 5mm die were fabricated for testing ISO 20795.1.2013 samples and $127 \mathrm{~mm} \times 12.7 \mathrm{~mm} \times 3.2 \mathrm{~mm}$ die were fabricated for ASTM D790 (8,9). The master die was duplicated with addition silicone impression material (Aquasil soft putty, Dentsply, Germany, Batch no:3162). The duplicated index was used to prepare wax test samples. 30 wax patterns for each group of the above mentioned dimension were prepared for both ISO and ASTM D790 standards. The dimensions of the specimens were verified using a calibrated digital vernier caliper. The wax samples were polymerized by conventional reverse flasking method. Type III gypsum dental stone (Gem stone Mahindra traders Chennai) was used for investing the wax pattern in dental flask. A layer of separating media (cold mold seal) was applied between two investment segments. With the final set of investment stone in the flask, the flask is placed in dewaxing unit to eliminate wax. Any residual wax was manually removed using the hand shower of the same machine. The cavity in the dental flask was used as matrices for the fabrication of heat polymerized acrylic resin specimens. A thin layer of cold mold seal (DPI) was painted over the stone of both flask halves. Heat cure acrylic resin was mixed with monomer in ratio of 3:1 in a porcelain jar. Acrylic resin was packed into the mold space in dough stage. A polythene sheet was placed over the resin and trial closures in the hydraulic press (Hydraulic Press P400, SIRIO Dental SRL) was done to ensure even flow of the resin throughout the mold space. This was repeated until no flash was observed. The flask was then tightened to $100 \mathrm{~N}$ using hydraulic press machines and bench curing was done for 20 min. The packed acrylic resin was processed by conventional short polymerization cycle, $70^{\circ} \mathrm{C}$ for 90 min and boiled for 1 hour. Once the curing process was finished, the flasks were bench cooled for $30 \mathrm{~min}$. The samples were de-flasked using a wooden mallet and plastic knife. The samples were finished and polished. The test specimens were subjected to grinding with acrylic burs. All the irregularities on the edges were adjusted using conventional acrylic burs by holding the specimen in a low speed dental lathe and followed by fine surface smoothness using 600 grid sand papers. Mechanical polishing performed with pumice slurry and chalk powder in combination of water for $30 \mathrm{~s}$. Group 1 (ISO samples) sample was cut into three equal strips before testing measuring $64 \mathrm{~mm}$ in length, $10 \mathrm{~mm}$ in width and $3.3 \mathrm{~mm}$ in height. The strips were trimmed and polished, all the edges and faces were smoothened and flattened to required size. The dimensions were verified using digital vernier calipers. The test specimens of ISO and ASTM were stored in water at a temperature of $37^{\circ} \mathrm{C}$ for 50 hours prior to flexural testing (14).

\section{Flexural strength}

The flexural strengths of the specimens were determined using a three-point and four-point bending test device in a universal testing machine INSTRON (Autograph universal testing machine, Shimadzu corp, Japan). The ISO specimen $(65 \mathrm{~mm} \times 40 \mathrm{~mm} \times 5 \mathrm{~mm})$ were rested on two supports and are loaded by means of a loading nose midway between the supports on the Universal Testing Machine for flexural strength evaluation. Load was applied at the center of the specimen with a cross head speed of $1.50 \mathrm{~mm} / \mathrm{min}$ and a span length of $40.00 \mathrm{~mm}$. The maximum load before fracture was measured. Flexural strength was calculated using the equation $(\mathrm{M}=3 \mathrm{Wl} / 2 \mathrm{bd} 2)$. The mean flexural strength of group was calculated, tabulated and the values were statically analyzed (Table 1 and 2)(15).

Table 1: Descriptive statistics of ISO Vs ASTM test specimen

\begin{tabular}{lcccc} 
Group & N & Mean ( MPa) & Standard deviation & Standard deviation error mean \\
\hline ISO & 30 & 60.492 & 0.803 & 0.146 \\
\hline ASTM & 30 & 61.470 & 1.370 & 0.250 \\
\hline
\end{tabular}

T test for equality of mean

\begin{tabular}{lcccc}
\hline & Sig (2 tailed) & $\begin{array}{c}\text { Mean error } \\
\text { difference }\end{array}$ & $\begin{array}{c}\text { Standard error } \\
\text { difference }\end{array}$ & $\begin{array}{c}\text { 95\% confidence interval } \\
\text { Upper limit }\end{array}$ \\
\hline Equal variance assumed & 0.001 & 0.978 & .290 & 0.397 \\
\hline Equal variance not assumed & 0.002 & 0.978 & .290 & 0.394 \\
\hline
\end{tabular}


The flexural strength of the ASTM specimen was evaluated by four point bend test. The test specimens $(127 \mathrm{~mm} \times$ $12.7 \mathrm{~mm} \times 3.2 \mathrm{~mm}$ ) were rested on the cylindrical support arm of the universal testing machine. In order to avoid excessive indentation, or failure due to stress concentration directly under the loading noses, the radii of the loading noses and supports was standardized to $5.0 \pm 0.1 \mathrm{~mm}$. The maximum load before fracture was measured. Flexural strength was calculated using the equation $\mathrm{S}=3 \mathrm{PL} / 4 \mathrm{bd} 2$. The mean flexural strength of group was calculated, tabulated and the values were statically analyzed (Table 1 and 2) (3).

\section{Results}

The mean flexural strength of was $60.492 \mathrm{MPa}$ and 61.470 MPa for ISO and ASTM specimens. The standard deviation of 0.803 and 1.370 was observed in both ISO and ASTM specimen. The results had $95 \%$ confidence interval, 0.310 , and 0.529 for both the groups. The distribution was equal and parametric $t$ test was done to analyze the results. The results were statistically significant with $P$ value $\leq 0.001$.

\section{Discussion}

The flexural strength of heat cure acrylic resin was evaluated in according to ISO 20795.1.2013 and ASTM D 6272 standards (3). These test methods are generally applicable to rigid and semi rigid material. The flexural properties determined by these methods are mostly used for quality control and research $(8,9)$. The study was done to determine the choice and use of appropriate protocol between 3 and 4 point testing protocol.

ASTM is a national organization that is a part of ISO organizations. ISO is an international organization that has representations from all countries including ASTM. ISO establishes documents and updates the standards of testing materials with global consensus from the experts of the associated national organizations. The products thus established are safe, quality and reliable. ISO standards are better valid since it developed and updated to the needs with the opinion of internationally established experts. The initial protocols of ISO had variations in testing procedures. Over the years constant modifications and changes have been made to the needs. Constant efforts have been made to match the testing protocols between the organizations to reduce the duplications of the tests and serve the community better. The standards for the day to determine flexural strength is ISO. Though directions have been issued towards for universal adaptation of latest ISO standards still many literatures employ ANSI or outdated ISO protocols $(8,9)$.

The difference between four and three point bending test exist in specimen size, shape, and thickness, load nose radius, bending momentum, maximum allowable strain and axial stress (3). The test specimen was $65 \mathrm{~mm} \times 40 \mathrm{~mm} \times 5 \mathrm{~mm}$ for three-point testing and measurement of $127 \mathrm{~mm} \times 12.7 \mathrm{~mm}$ $x 3.2 \mathrm{~mm}$ for four point bending test testing. In dentistry, the samples for ISO testing were easy to fabricate in regular dental flasks compared to larger specimens of four point bending test. The ASTM samples required larger flasks to fabricate and polymerize PMMA specimen. The variations in samples sizes and protocol do not differentiate the results significantly.
The mean flexural strength of Group ISO is $60.49 \mathrm{MPa}$ and Group ASTM is $61.44 \mathrm{MPa}$. The results matched the manufacturer and ideal values of flexural strength of denture base materials. The test found no statistical differences between the two methods. But quantitatively ASTM is slightly higher than ISO. Flexural properties in both protocols may vary with in accordance specimen depth, temperature, atmospheric condition and rate of strain. The quantitative variability in this study can be due to the stress distribution. In 4-point bending test the axial stress are uniformly distributed between the loading points compared to 3-point bending test where the maximum axial stress is located immediately under the loading points (9).

The mechanism of stress evaluation can display a minor variation in the strength value. Both the protocols are reliable testing methods. The test sensitivity is less in 4 point compared to 3 point bending test. This makes the 4 point test more ideal for composite and brittle materials. Literatures have determined $10 \%$ variations between the ASTM and older ISO protocols (9) . ISO has adapted and modified to the needs of the situations and for dental materials it is more ideal in terms of sample fabrication to mechanical testing (8).

The study evaluated the conventional heat cure specimens without any modifications to the compositions. Further studies are required to determine the influence of testing protocol with changes in composition, reinforcement, composite materials of PMMA and the influence in the testing protocols.

\section{Conclusion}

A comparison of the results from three-point and fourpoint bend tests of denture-base polymers showed no significant statistically and clinical differences in the flexural strength. However, flexural strength values were higher in four-point bending than in three-point bending.

Türkçe Öz: Protez kaide reçinelerinin bükülme dayanımının belirlenmesinde ISO ve ASTM standartlarının karşılaştırılması. Amaç: Isı ile polimerize olan polimetilmetakrilat (PMMA) protez kaide reçinelerinin bükülme dayanımının belirlenmesinde kullanılan metodoloji standartlarında farklılıklar mevcuttur. ASTM ve farklı ISO standartları, materyalin bükülme dayanımını belirlemek için literatürde uyarlanan protokollerdir. Etkili, kabul edilebilir ve standartlar arası farklııkları belirlemeye ihtiyaç duyulmaktadır. Gereç ve Yöntem: Bu çalışmanın amacı, protez kaide reçinelerinin bükülme dayanımının değerlendirmek için ideal standardın belirlenmesidir. Amaç, Isı ile polimerize olan PMMA protez kaide reçinelerinin bükülme dayanımlarını ölçmek için kullanılan ASTM D790 ve ISO 20795.1.2013 arasındaki farkları karşılaştırmaktır. 30 adet ISI ile polimerize olan protez kaide örneği ISO 20795.1.2013 ve ASTM D790 standartlarına uygun olarak üretilmiştir. Örnekler rutin olarak kullanılan protocol ile bitirilip muhafaza edilmiştir. Bükülme dayanımı, $1.50 \mathrm{~mm}$ / dak yaklaşma hızında ve $40.00 \mathrm{~mm}$ bir açıklık uzunluğunda üniversal test makinesi kullanılarak belirlenmiştir. Ortalama bükülme dayanımı değerleri MPa olarak elde edilmiş, tabloya aktarılmış ve student $t$ testi ile istatistiksel olarak analiz edilmiştir. Bulgular: ISO ve ASTM tarafından bulunan ısı ile polimerize olan PMMA'nın ortalama bükülme dayanım değerleri, $60.492 \mathrm{MPa}$ ve $61.470 \mathrm{MPa}$ arasında değişmiştir. Iki yöntem arasında anlamlı fark bulunmamıştır. Sonuçlar istatistiksel olarak $P \leq 0.05$ anlamlı bulunmamıştır. Sonuç: Isı ile polimerize olan PMMA protez kaide reçinelerinin bükülme dayanım değerlerinde ISO 20795.1.2013 ve ASTM 790 protokolleri arasındaki sayısal farklılıklar mevcuttur. Fakat bu farklılıklar, istatistiksel ve klinik olarak anlamlı değildir. Anahtar kelimeler: ISO; ASTM; protez kaide reçinesi; polimetilmetakrilat. 
Peer-review: Externally peer-reviewed.

Author contributions: NGC, VJ and VS designed the study. NGC and VS participated in generating the data for the study. NGC and VS participated in gathering the data for the study. NGC and VS participated in the analysis of the data. NGC wrote the majority of the original draft of the paper. NGC, VJ and VS participated in writing the paper. All authors approved the final version of this paper.

Conflict of Interest: The author had no conflict of interest to declare.

Financial Disclosure: The author declared that this study has received no financial support.

\section{References}

1. Chander NG. Polymethyl metha acrylate denture base. An overview. J Indian Prosthodont Soc 2018;18:87-8. [CrossRef]

2. Gad MM, Fouda SM, Al-Harbi FA, Näpänkangas R, Raustia A. PMMA denture base material enhancement: a review of fiber, filler, and nanofiller addition. Int J Nanomedicine 2017;12:38011. [CrossRef]

3. Chitchumnong P, Brooks SC, Stafford GD. Comparison of three- and four-point flexural strength testing of denture-base polymers. Dent Mater 1989;5:2-5. [CrossRef]

4. Sweeney WW, Caul HJ, Genug WA. Transverse Testing Machine for Denture Resins, J Am Dent Assoc 1954;49:174-6. [CrossRef]

5. Osborne J.Transverse Tests on Denture Base Materials, Br Dent J 1949;86:64-7.

6. Souder W, and Paffenbarger GC. Physical Properties of Dental Materials, Circular C433, National Bureau of Standards, Washington, DC. US Government Printing Office, 1942:173.

7. Stafford GD, Bates JF, Huggett R and Handley RW. A Review of the Properties of Some Denture Base Polymers. Br Dent J 1980;8:292-306. [CrossRef]
8. International Organization for Standardization. ISO 20795-1: 2013. Dentistry - Base polymers- Part 1: Denture base polymers. Geneva: ISO 2013:1-42.

9. American Society for Testing and Materials. ASTM Standard D 790-02. Standard Test Methods for Flexural Properties of Unreinforced and Reinforced Plastics and Electrical Insulating Materials. ASTM International, West Conshohocken, United States. ASTM 2002:146-54.

10. Jagger DC, Harrison A, Jandt KD. The reinforcement of dentures. J Oral Rehabil 1999;26:185-94. [CrossRef]

11. Vallittu PK. A review of fiber-reinforced denture base resins. J Prosthodont 1996;5:270-6. [CrossRef]

12. Somkuwar S, Mishra SK, Agrawal B, Choure R. Comparison of the flexural strength of polymethyl methacrylate resin reinforced with multiwalled carbon nanotubes and processed by conventional water bath technique and microwave polymerization. J Indian Prosthodont Soc 2017;17:332-9. [CrossRef]

13. Ucar Y, Akova T, Aysan I. Mechanical properties of polyamide versus different PMMA denture base materials. J Prosthodont 2012;21:173-6. [CrossRef]

14. Harini P, Mohamed K, Padmanabhan TV. Effect of Titanium dioxide nanoparticles on the flexural strength of polymethylmethacrylate: an in vitro study. Indian J Dent Res 2014;25:459-63. [CrossRef]

15. Venkat R, Gopichander N, Vasantakumar M. Comprehensive analysis of repair/reinforcement materials for polymethyl methacrylate denture bases: mechanical and dimensional stability characteristics. J Indian Prosthodont Soc 2013;13:43949. [CrossRef]

16. Phoenix RD, Mansueto MA, Ackerman NA, Jones RE. Evaluation of mechanical and thermal properties of commonly used denture base resins. J Prosthodont 2004;13:17-27. [CrossRef] 